ISSN 0258-7122

Bangladesh J. Agril. Res. 34(1) : 143-155, March 2009

\title{
EFFECT OF IRRIGATION LEVELS AT DIFFERENT GROWTH STAGES ON GROWTH PARAMETERS AND YIELD OF FOUR SELECTED CHILLI ACCESSIONS
}

\author{
M. A. I. KHAN ${ }^{1}$, A. M. FAROOQUE ${ }^{2}$, M. A. HOQUE ${ }^{3}$, \\ M.A. RAHIM ${ }^{4}$ AND M. A. HAQUE ${ }^{5}$
}

\begin{abstract}
An experiment as conducted at Bangladesh Agricultural University. Mymensingh in poly bags under glasshouse condition during October 1997 to March 1998 to know the effects of different water levels at different growth stages of four selected chilli accessions viz., C-027l, C-0272, C-0275, and C0277. Six water treatments viz., watering once everyday $\left(\mathrm{W}_{1}\right)$, watering twice everyday $\left(\mathrm{W}_{2}\right)$. watering at 4 days interval $\left(\mathrm{W}_{3}\right)$, watering at 8 days interval $\left(\mathrm{W}_{4}\right)$, watering at 16 days interval $\left(\mathrm{W}_{5}\right)$, and no watering $\left(\mathrm{W}_{0}\right)$ were tested at three growth stages viz., Vegetable stage $\left(\mathrm{S}_{1}\right)$, Flowering stage $\left(\mathrm{S}_{2}\right)$, and Fruiting stage $\left(S_{3}\right)$. The accessions of chilli were selected from the results of a previous experiment where ten accessions of chilli collected from Spices Research Centre (SRC) of Bangladesh Agricultural Research Institute, Joydebpur, Gazipur were used. The primary selection was made on the basis of their tolerance and susceptibility to water stages. The results revealed that all the studied parameters viz., plant height, canopy diameter, root length, root volume, no. of fruits per plant, fruit length, fruit diameter, individual fruit weight, no. of leaves per plant, leaf area per plant, fruit yield per plant, leaf dry weight, stem dry weight, root dry weight, fruit dry weight per plant, varied significantly among the accessions under different water treatments at different stages of growth. Out of four accessions, C-0271 and C-0277 were found as water stress tolerant and susceptible, respectively.
\end{abstract}

Key Words: Water level, growth stage, chilli accessions.

\section{Introduction}

The genus Capsicum has to commercial species viz., Capsicum annum and Capsicum fruitescens which are commonly cultivated in Bangladesh. The chilli farmers in Bangladesh cultivate their crop mostly under rainfed condition (Hossain, 1990). Irrigated chilli exists only in a few localized commercial spots. So, it is very important to have some cultivars with good yield potentials that can be grown under rainfed condition and/or under partial irrigation. In Bangladesh,

\footnotetext{
${ }^{1}$ Chief Scientific Officer, Horticulture Research Centre, BARI, Joydebpur, Gazipur-1701.

${ }^{2}$ Vice Chancellor, SAU, Dhaka, ${ }^{3}$ Senior Scientific Officer, Tuber Crops Research subCentre, BARI, Munshiganj, ${ }^{4}$ Professor, Deptt. of Horticulture, BAU, Mymensingh, ${ }^{5}$ Professor, Deptt. of Crop Botany, BAU, Mymensingh, Bangladesh.
} 
farmers grow many cultivars of chilli. Investigation is needed to find out chilli cultivars that have tolerance to stress from both deficit and excess soil moisture. These selected cultivars are expected to exhibit characteristics to withstand the above moisture stress situations. The present experiment was conducted to identify water (moisture) stress (deficit \& excess) tolerant varieties of chilli from the existing chilli cultivars in the country. The specific objective was to find out the effects of different levels of water at vegetative, flowering, and fruiting stages of chilli plants on the physio-miorphological and fruiting characters of four preselected accessions of local chilli cultivars being used by the farmers of Bangladesh.

\section{Materials and Method}

The experiment was set with the plants growing in polybags in the glasshouse of Bangladesh Agricultural University, Mymensingh during October 1997 to March 1998. Four accessions of chilli viz., C-0271 $\left(\mathrm{V}_{1}\right)$, C-0272 $\left(\mathrm{V}_{2}\right), \mathrm{C}-0275\left(\mathrm{~V}_{3}\right)$, and C-0277 $\left(\mathrm{V}_{4}\right)$ were selected for this experiment from a study with ten accessions. The accessions were originally collected from Spices Research Centre of Bangladesh Agricultural Research Institute (BARI), Joydebpur, Gazipur.

\section{Water treatments}

Six water treatments were, $\mathrm{W}_{1}=$ watering once daily, $\mathrm{W}_{2}=$ watering twice daily. $\mathrm{W}_{3}=$ watering at 4 days interval, $\mathrm{W}_{4}=$ Watering at 8 days interval, $\mathrm{W}_{5}=$ Watering at 16 days interval and $\mathrm{W}_{0}=$ no watering (control).

\section{Growth stages}

Three growth stages were, $S_{1}=$ Vegetative stage, $S_{2}=$ Flowering stage, and $S_{3}=$ Fruiting stage.

\section{Determination of poly bag capacity of moisture and application of water treatments}

Poly bag capacity (analogue to field capacity) of the growing medium was determined so as to maintain optimum and uniform moisture level particularly at the time of seed sowing. To determine poly bag capacity, randomly selected 3 bags from each replication were evenly watered until water leaked through the bottom. After 8 hours of drainage, sand or compost samples were collected in soil core and oven dried at 80 (for 72 hours. The moisture contents of the samples were determined and used in determining the poly bag capacity of the total preweighed growing medium of the experiment. 
Different water treatments were imposed according to the moisture levels on desired in the experiment. The watering was stopped one day before imposing of water treatment. Before every time of water treatment application, an estimate was made by randomly selecting three bags of each treatment and watering them slowly until leaked from the base. After two hours of drainage, the leaked water was measured and subtracted from the original volume applied and considered it to be the optimum bag capacity and that volume was given to all other bags of the same treatment (Hamid, 1993).

Table 1. Effect of four chilli cultivars on the physio-morphological characters.

\begin{tabular}{l|l|l|l|l|l|l}
\hline \multicolumn{1}{c}{ Characters } & \multicolumn{1}{c}{ CO271 } & \multicolumn{1}{c}{ C0272 } & C0275 & C0277 & LSD(0.05) & CV (\%) \\
\hline No. of leaves/plant & 288.98 & 218.25 & 254.23 & 318.29 & 10.80 & 10.61 \\
Leaf area/plant (cm ${ }^{2}$ ) & 2328.66 & 1451.07 & 2107.42 & 2620.15 & 61.35 & 7.64 \\
Plant height (cm) & 69.61 & 62.55 & 65.61 & 73.22 & 2.62 & 10.28 \\
Canopy diameter (cm) & 47.26 & 34.20 & 42.62 & 52.04 & 1.98 & 11.91 \\
Root length (cm) & 468.87 & 410.25 & 399.49 & 432.48 & 17.92 & I . II \\
Root volume (cc) & 10.06 & 8.67 & 9.23 & 10.60 & 0.26 & 7.21 \\
No. of fruits/plant & 133.12 & 118.83 & 137.13 & 153.91 & 3.13 & 6.11 \\
Fruit length (mm) & 30.49 & 25.57 & 28.36 & 33.35 & 1.30 & II .72 \\
Fruit diameter (mm) & 6.77 & 6.22 & 6.56 & 7.41 & 0.23 & 8.92 \\
Individual fruit weight (mg) & 382.48 & 309.46 & 357.07 & 398.24 & 12.36 & 9.06 \\
Fruit yield/plant (g) & 52.77 & 34.69 & 43.19 & 62.97 & 1.46 & 8.01 \\
Leaf dry wt (g) & 3.71 & 3.04 & 3.60 & 4.23 & 0.18 & 13.20 \\
Stern dry wt (g) & 7.86 & $7.3 \mathrm{I}$ & 7.69 & 8.70 & 0.34 & 11.45 \\
Root dry wt (g) & 2.42 & 1.76 & 2.18 & 2.86 & 0.09 & 10.53 \\
Fruit dry wt/plant (g) & 13.13 & 8.52 & 10.96 & 15.60 & 0.46 & 10.16 \\
\hline
\end{tabular}

\section{Soil medium and seed sowing}

The poly bags in each block were arranged in North-South rows for proper sunlight absorption. Each bag in the experiment was watered to bag capacity level one to two days before sowing of seeds. Following emergence, bags were watered as and when necessary before imposition of water treatments. Poly bags of $30 \mathrm{~cm}$ x $20 \mathrm{~cm}$ size were filled in with a mixture of soil, sand, and compost in equal proportion (Muthukrishnan et at, 1983). Six seeds were sown in each hag and after germination, seedlings were thinned to one for conducting experiment. N:P:K fertilizers @ 250:160:250 mg were applied in each bag after 10 to 15 days of treatment imposition (Anon., 2005). Fertilization was followed by irrigation. 


\section{Results and Discussion}

In the experiment, the excess water treatments, $\mathrm{W}_{1}$ and $\mathrm{W}_{2}$ and the deficit water treatments, $\mathrm{W}_{5}$ and $\mathrm{W}_{0}$ were considered as water stress treatments, while $\mathrm{W}_{3}$ and $\mathrm{W}_{4}$ were considered optimum and semi optimum water level treatments, respectively. The individual effects of accessions, growth stages, and water treatments are shown in the Table 1, 2, and 3, respectively.

As seen from the Table 3, the individual effects of water treatments have large influence on the physio-morphological and yield characters of chilli accessions, the water treatments, $\mathrm{W}_{3}$ and $\mathrm{W}_{4}$ produced higher values and $\mathrm{W}_{1}, \mathrm{~W}_{2}$, $\mathrm{W}_{5}$ and $\mathrm{W}_{0}$ produced lower values of all the parameters studied. This indicates that $\mathrm{W}_{3}$ and $\mathrm{W}_{4}$ produced no or non-harmful stresses, whereas, the others produced yield reducing stresses.

Fable 2. Effect of growth stage on the physio-rnorphological characters of four cultivars (accessions) of chilli.

\begin{tabular}{l|l|l|l|l|l}
\hline \multicolumn{1}{c}{ Characters } & \multicolumn{1}{c|}{$\mathrm{S}_{1}$} & \multicolumn{1}{c|}{$5_{2}$} & \multicolumn{1}{c}{$\mathrm{S}_{3}$} & \multicolumn{1}{c}{ LSD (0.05) } & CV (\%) \\
\hline No. of leaves/plant & 255.8 & 285.8 & 268.2 & 6.28 & 10.61 \\
Leaf area/plant(crn ${ }^{2}$ ) & 2015.54 & 2222.97 & 2141.97 & 38.41 & 7.65 \\
Plant height (cm) & 64.14 & 72.03 & 67.07 & 4.2 & 10.28 \\
Canopy diameter (cm) & 40.57 & 47.68 & 43.84 & 1.43 & 11.91 \\
Root length (cm) & 405.64 & 427.08 & 450.61 & 13.2 & 11.11 \\
Root volume (cc) & 9.21 & 9.43 & 10.29 & 0.66 & 7.21 \\
No. of fruits/plant & 106.96 & 153.67 & 146.61 & 4.33 & 6.11 \\
Fruit length (mm) & 31.2 & 26.68 & 30.45 & 1.6 & 11.72 \\
Fruit diameter (mm) & 7.08 & 6.23 & 6.9 & 0.28 & 8.92 \\
Individual fruit wt .(rng) & 456.31 & 296.7 & 332.42 & 35 & 9.06 \\
Fruit yield/plant (g) & 47.92 & 46.94 & 50.36 & 1.95 & 8.01 \\
leaf dry wt. (g) & 3.47 & 3.92 & 3.55 & 0.089 & 13.2 \\
Stem dry wt. (g) & 7.45 & 8.49 & 7.74 & 0.46 & 11.45 \\
Root dry wt. (g) & 2.21 & 2.25 & 2.46 & 0.3 & 10.53 \\
Fruit dry wt./plant (g) & 12.16 & 11.16 & 12.84 & 0.27 & 10.16 \\
\hline
\end{tabular}

The combined effects of chilli accessions, growth stages and water sequence are shown in Table 4 . The Table reflects the similar trend as that produced by the individual effects of water treatments. The domination of water treatment effects is very clear from the values shown in the Table 4 for all the physiomorphological and yield parameters studied. Here, the water treatments $\mathrm{W}_{3}$ and $\mathrm{W}_{4}$ produced the highest and the second highest values of the parameters, 
respectively. On the other hand, the treatments, $\mathrm{W}_{1}, \mathrm{~W}_{2}, \mathrm{~W}_{5}$, and $\mathrm{W}_{0}$, produced lower values of the parameters in combination with chilli accessions and growth stages.

The above stated results indicate the non-stressness of the water treatments, $\mathrm{W}_{3}$, and $\mathrm{W}_{4}$ and stressness of the treatments, $\mathrm{W}_{1}, \mathrm{~W}_{2}, \mathrm{~W}_{5}$, and $\mathrm{W}_{0}$, respectively. This fact became true for both individual effect as well as combined effect of chilli accessions, growth stages, and water levels.

Table 3. Effect of water treatment on the phvsio-rnorphological characters of thur cultivars (accessions) of chilli

\begin{tabular}{lcccc|c|c|c|c|c}
\hline \multicolumn{1}{c}{ Characters } & $\mathrm{W}_{1}$ & $\mathrm{~W}_{2}$ & $\mathrm{~W}_{3}$ & $\mathrm{~W}_{4}$ & $\mathrm{~W}_{5}$ & $\mathrm{~W}_{0}$ & LSD $_{0.05}$ & $\mathrm{CV}(\%)$ \\
\hline No. of leaves/plant & 227.00 & 257.00 & 380.20 & 305.00 & 227.00 & 223.50 & 16.85 & 10.61 \\
Leaf area/plant (cm ${ }^{2}$ ) & 1838.51 & 2061.84 & 2893.4 & 2185.11 & 1949.54 & 1832.57 & 91.14 & 7.65 \\
Plant height (cm) & 66.25 & 69.40 & 73.57 & 70.92 & 65.76 & 60.57 & 3.61 & 10.28 \\
Canopy diameter (cm) & 39.70 & 44.39 & 52.98 & 47.56 & 41.38 & 38.16 & 2.10 & 11.91 \\
Root length (cm) & 420.20 & 419.90 & 446.44 & 442.09 & 423.41 & 414.61 & 17.00 & 11.11 \\
Root volume (cc) & 9.65 & 9.09 & 10.43 & 9.73 & 9.71 & 9.23 & 0.60 & 7.21 \\
No. of fruits/plant & 134.06 & 117.70 & 173.30 & 155.00 & 123.36 & 111.00 & 9.65 & $6 . \mathrm{II}$ \\
Fruit length (mm) & 23.75 & 27.67 & 39.26 & 35.21 & 25.95 & 24.83 & 1.96 & 11.72 \\
Fruit diameter (mm) & 6.33 & 6.61 & 7.76 & 7.12 & 6.54 & 6.07 & 0.51 & 8.92 \\
Individual fruit wt. (mg) & 314.88 & 345.81 & 440.67 & 392.72 & 356.20 & 320.59 & 35.07 & 9.06 \\
Fruit yield/plant (g) & 42.67 & 34.89 & 71.20 & 59.90 & 44.24 & 37.54 & 2.83 & 8.01 \\
Leaf dry wt. (g) & 3.09 & 3.76 & 4.55 & 4.05 & 3.32 & 3.11 & 0.16 & 13.20 \\
Stem dry wt. (g) & 7.46 & 8.02 & 8.66 & 8.36 & 7.72 & 7.10 & 0.51 & 11.45 \\
Root dry wt. (g) & 2.04 & $\mathrm{I} .61$ & 2.93 & 2.80 & 2.45 & 2.00 & 0.26 & 10.53 \\
Fruit dry wt./plant (g) & 9.63 & 8.01 & 17.16 & 16.01 & $\mathrm{II} .45$ & 10.07 & $\mathrm{I} .08$ & 10.16 \\
\hline
\end{tabular}

The number of leaves and leaf area per plant are found small in deficit moisture treatments, $\mathrm{W}_{5}$ and $\mathrm{W}_{0}$ and excess moisture treatments. $\mathrm{W}_{1}$ and $\mathrm{W}_{2}$ (Table 3). Horton et al. (1982) reported fewer leaves per chilli plant with the drier treatments. Lower leaf area of chilli varieties with drier treatments was observed by Beese et al. (1982). So, the present findings on the number of leaves and leaf area per plant are in agreement with the above findings. The plant height, root length, root volume, leaf dry weight, stem dry weight, and root dry weight were also affected by the water stress in plants. Beese et al. (1982) reported reduction in final yields of above and under ground plant parts in chilli due to moisture stress effect. Many researchers have found lower values of many 
growth parameters including dry weight of different plant parts resulted from water stress (Ayob, 1986; Beese and Moshrefi, 1985: Hedge, 1989; Smittle et al., 1994). The present findings reflect the substantiality of the results when these are compared. The total dry weight reduction are in fact due to the reduction of growth relating parameters like leaf stem and root of chilli plants. The water treatments in combination with growth stages and accessions gave the similar trend as that of their individual effects on the growth parameters (Table 4).

The number of fruits per plant, fruit length and diameter, individual fruit weight, fruit yield per plant, and fruit dry weight per plant were affected by the water stress of either deficit or excess conditions (Table 3). The lowest values of these parameters were produced by either deficit or excess water treatments. Techawongstein el al. (1992) reported that in chilli, the number of fruits per plant, fruit length, and diameter and individual fruit weight have been found to be less in water stressed plants than those in optimum level of water. Hedge (1989) observed the adverse effect of both excess and deficit soil moisture on the fruit yield of chilli. Lower fruit yield in chilli was also reported by Ayob (1986) with excess and deficit soil moisture. The growth and yield of chilli showed declining trend with higher levels of irrigation (Sadykov and Mikhoet, 1981). So, the present response of physio-morphological and yield contributing parameters to the excess and deficit water treatments are in agreement with the previous works.

Under the combined effect of three factors- accessions, growth stages, and water regime, the number of fruits per plant were found sensitive to excess moisture condition at vegetative stage (seedling stage). The leaf, stem, and root dry weight subjected to stress at the seedling stage of chilli accessions were found lower than that subjected at the matured stage (Table 4). Techawongstein et al. (1992) observed similar result with the same parameters. The stress, developed in plants after imposing the treatments markedly suppressed the vegetative growth and the plants became stunted. Although the yield was observed to differ significantly among the accessions due to stress at all stages, the number of fruits was more affected than the individual fruit weight When the stress was given at older stages, the reduction in yield had not been found so high (Table 4). Techawongstein et al. (1992) reported similar observation on chilli. According to them, the plants suffered from deficit water at the vegetative stage produced less number of fruits and those suffered at the matured stage produced less fruit weight. The reduction in number of fruits in the vegetative stage resulted from poor flower bud formation and poor development of fruit. The 
Table 4. Combined effect of growth stage, water treatment and cultivar on the physio-morphological characters of chilli.

\begin{tabular}{|c|c|c|c|c|c|c|c|c|c|c|c|c|c|c|c|}
\hline $\mathrm{S}_{\mathrm{x}} \mathrm{W}_{\mathrm{y}} \mathrm{V}_{\mathrm{z}}$ & 1 & 2 & 3 & 4 & 5 & 6 & 7 & 8 & 9 & 10 & II & 12 & 13 & 14 & 15 \\
\hline $\mathrm{S}_{1} \mathrm{~W}_{1} \mathrm{~V}_{1}$ & 7.63 & 39.27 & 2.37 & 7.79 & 5.28 & 9.84 & .19 & 23.88 & 6.79 & 371.70 & 45.89 & 3.02 & 7.04 & 2.11 & 0.86 \\
\hline${ }_{1} \mathrm{~W}_{1} \mathrm{~V}_{2}$ & 164.30 & I 100.93 & $57.4 !$ & 24.72 & 379.55 & 8.07 & 82.17 & 21.64 & 5.54 & 372.47 & 30.11 & 2.35 & 6.45 & 1.39 & .20 \\
\hline $\mathrm{W}_{1} \mathrm{~V}_{3}$ & 184.97 & 1600.20 & 59. & 3 & 35 & 8. & 92.23 & 51 & 30 & .77 & 76 & 92 & 34 & 75 & 048 \\
\hline $\mathrm{W}_{1} \mathrm{~V}_{4}$ & 245.33 & 2167.00 & 66.45 & 4 & 0.87 & 10.23 & 8.54 & 29.17 & $7.6 !$ & 450.47 & 59.67 & 3.46 & 7.62 & 2.69 & 2.17 \\
\hline${ }_{1} \mathrm{~W}_{2} \mathrm{~V}_{1}$ & 245.17 & 2107.12 & 68.10 & 43.57 & 410.33 & 9.47 & 94.73 & 31.13 & 6.86 & 180.73 & 33.81 & 3.67 & 7.44 & 1.83 & 8.05 \\
\hline${ }_{1} \mathrm{~W}_{2} \mathrm{~V}_{2}$ & 198.70 & 1233.33 & 60.84 & 30.39 & 330.56 & 8.14 & 84.39 & 26.37 & 6.34 & 370.73 & 28.45 & 3.05 & 6.93 & 1.32 & 6.75 \\
\hline${ }_{1} \mathrm{~W}_{2} \mathrm{~V}_{3}$ & 228.70 & 2034.47 & 63.12 & 38.44 & 388.89 & 8.04 & 91.42 & 29.27 & 6.63 & 478.53 & 32.97 & 3.48 & 733 & 1.65 & 8.27 \\
\hline${ }_{1} \mathrm{~W}_{2} \mathrm{~V}_{4}$ & 271.93 & 2377.70 & 70.47 & 46.64 & 390.66 & 9.63 & 113.63 & 35.27 & 7.47 & 479.87 & 46.97 & 4.03 & 8.21 & 2.12 & 11.65 \\
\hline & 39170 & $2 \varepsilon$ & 7 & 53.2 & & & & & 7.66 & & & 4. & 8.03 & 3.04 & 59 \\
\hline${ }_{1} \mathrm{~W}_{3} \mathrm{~V}_{2}$ & 307.97 & 2201170 & 61.44 & 37.48 & 410. 48 & 9.23 & 116.45 & 3670 & 6.77 & 460.07 & 39.33 & 398 & 7.54 & 2.31 & 9.79 \\
\hline${ }_{1} \mathrm{~W}_{3} \mathrm{~V}_{3}$ & 376.03 & 2397.53 & 68.22 & 47.33 & 406.10 & 9.73 & I 39.04 & 40.73 & 7.36 & 503.93 & 54.80 & 3.96 & 7.78 & 2.85 & I 2.49 \\
\hline${ }_{1} \mathrm{~W}_{3} \mathrm{~V}_{4}$ & 431.67 & 3428.87 & 73.78 & 58.45 & 468.33 & 11.09 & 141.48 & 46.53 & 9.97 & 692.87 & 104.10 & 4.76 & 8.97 & 3.52 & 2513 \\
\hline${ }_{1} \mathrm{~W}_{4} \mathrm{~V}_{1}$ & 298 & 2253.60 & 69 & & & & & 39 & 3 & $57:$ & 20.12 & 3. & 7.75 & 2.67 & 19.31 \\
\hline${ }_{1} \mathrm{~W}_{4} \mathrm{~V}_{2}$ & 238.61 & 377.60 & 61.88 & 34.40 & & 8.50 & & 32.63 & 7.03 & 532.60 & 48.12 & 40 & 7.25 & 2. 03 & 12.93 \\
\hline $\mathrm{S}_{1} \mathrm{~W}_{4} \mathrm{~V}_{3}$ & 278.49 & 2156.97 & 64.24 & 43.64 & 395.88 & 8.97 & 114.00 & 37.83 & 7.57 & 470.10 & 49.32 & 3.77 & 7.70 & 2.49 & 13.36 \\
\hline $\mathrm{S}_{1} \mathrm{~W}_{4} \mathrm{~V}_{4}$ & 338.47 & 2431.73 & 71.22 & 51.16 & 427.13 & I 0.27 & 118.68 & 41.57 & 8.07 & 542.90 & 71.96 & 4.29 & 8.71 & 4.07 & 19.55 \\
\hline${ }_{1} \mathrm{~W}_{5} \mathrm{~V}_{1}$ & 223.63 & I 997.20 & 61.42 & 41.14 & 148.07 & 9.60 & 86.92 & 29.53 & 7.07 & 505.27 & 45.44 & 3. 20 & 7.23 & 234 & I2.35 \\
\hline${ }_{1} \mathrm{~W}_{5} \mathrm{~V}_{2}$ & $17 ! .03$ & 1169.20 & 55.18 & $28.0 !$ & 379.70 & 8.14 & 80.68 & 25.07 & 6.73 & 370.27 & 29.36 & 2.47 & 6.64 & 1.72 & 7.95 \\
\hline${ }_{1} \mathrm{~W}_{5} \mathrm{~V}_{3}$ & 208.53 & 1909.20 & 58.99 & 35.58 & 389.97 & 8.53 & 94.28 & 26.83 & 7.00 & 519.97 & 43.32 & 3.08 & 7.03 & 2.10 & 12.11 \\
\hline
\end{tabular}


Table 4. Cont'd

\begin{tabular}{|c|c|c|c|c|c|c|c|c|c|c|c|c|c|c|c|}
\hline $\mathrm{S}_{\mathrm{x}} \mathrm{W}_{\mathrm{y}} \mathrm{V}_{\mathrm{z}}$ & I & 2 & 3 & 4 & 5 & 6 & 7 & 8 & 9 & 10 & II & 12 & 13 & 14 & 15 \\
\hline $\mathrm{S}_{1} \mathrm{~W}_{0} \mathrm{~V}_{1}$ & 251.02 & 1996.99 & 61.05 & 41.59 & 403.27 & 9.09 & 108.24 & 25.06 & 6.08 & 336.45 & 39.96 & 3.05 & 7.13 & 1.99 & 10.72 \\
\hline $\mathrm{S}_{1} \mathrm{~W}_{0} \mathrm{~V}_{3}$ & 214.19 & 1932.18 & 58.43 & 36.78 & 345.20 & 8.12 & 111.99 & 23.22 & 5.98 & 350.85 & 38.12 & 3.06 & 6.93 & 1.65 & 10.38 \\
\hline $\mathrm{S}_{1} \mathrm{~W}_{0} \mathrm{~V}_{4}$ & 243.58 & 2225.12 & 66.88 & 45.30 & 415.10 & 9.66 & 126.48 & 26.26 & 6.50 & 335.22 & 4627 & 3.80 & 7.80 & 2.45 & 12.24 \\
\hline $\mathrm{S}_{2} \mathrm{~W}_{1} \mathrm{~V}_{2}$ & 187.40 & 1232.17 & 67.38 & 36.48 & 440.20 & 8.50 & 139.60 & 19.30 & 5.20 & 248.40 & 28.96 & 2.64 & 7.54 & 1.12 & 6.05 \\
\hline $\mathrm{S}_{2} \mathrm{~W}_{1} \mathrm{~V}_{3}$ & 210.73 & 1787.30 & 69.70 & 44.35 & 382.53 & 9.33 & 155.08 & 20.24 & 5.47 & 247.33 & 41.60 & 3.31 & 8.00 & 1.47 & 7.33 \\
\hline $\mathrm{S}_{2} \mathrm{~W}_{1} \mathrm{~V}_{4}$ & 308.77 & 2427.03 & 77.69 & 52.88 & 422.50 & 10.53 & 183.52 & 24.57 & 5.87 & 298.87 & 54.52 & 3.92 & 8.92 & 2.39 & 11.33 \\
\hline $\mathrm{S}_{2} \mathrm{~W}_{2} \mathrm{~V}_{1}$ & 293.07 & 2360.07 & 77.51 & 53.46 & 470.89 & 8.80 & 125.88 & 23.80 & 6.40 & 278.30 & 30.93 & 4.20 & 8.70 & 1.71 & 6.43 \\
\hline $\mathrm{S}_{2} \mathrm{~W}_{3} \mathrm{~V}_{1}$ & 425.63 & 3188.60 & 81.60 & 60.50 & 458.28 & 11.11 & 193.48 & 37.77 & 7.50 & 399.97 & 82.56 & 5.02 & 9.41 & 3.37 & 20.39 \\
\hline $\mathrm{S}_{2} \mathrm{~W}_{3} \mathrm{~V}_{2}$ & 343.60 & 2469.23 & 73.38 & 44.22 & 455.63 & 8.24 & 172.48 & 30.57 & 6.53 & 270.03 & 43.72 & 4.15 & 8.82 & 1.89 & 9.99 \\
\hline $\mathrm{S}_{2} \mathrm{~W}_{3} \mathrm{~V}_{3}$ & 386.60 & 2685.23 & 77.75 & 54.57 & 405.07 & 10.62 & 206.62 & 35.47 & 7.13 & 304.03 & 58.32 & 4.95 & 9.11 & 3.18 & 13.27 \\
\hline $\mathrm{S}_{2} \mathrm{~W}_{3} \mathrm{~V}_{4}$ & 454.04 & 3840.33 & 83.98 & 67.29 & 428.77 & 10.41 & 227.60 & 40.53 & 7.77 & 407.67 & 98.88 & 5.54 & 10.51 & 2.98 & 22.24 \\
\hline $\mathrm{S}_{2} \mathrm{~W}_{4} \mathrm{~V}_{1}$ & 350.80 & 252.07 & 80.41 & 54.39 & 485.00 & 10.23 & 185.60 & 33.27 & 6.63 & 337.00 & 67.20 & 4.45 & 9.07 & 2.87 & 17.15 \\
\hline $\mathrm{S}_{2} \mathrm{~W}_{4} \mathrm{~V}_{2}$ & 277.30 & 1542.93 & 69.358 & 40.83 & 423.43 & 8.70 & 160.39 & 25.10 & 6.20 & 289.23 & 45.72 & 3.89 & 8.45 & 2.22 & 11.55 \\
\hline $\mathrm{S}_{2} \mathrm{~W}_{4} \mathrm{~V}_{3}$ & 297.87 & 2415.77 & 73.26 & 48.16 & 396.43 & 9.57 & 188.28 & 31.53 & 6.27 & 268.93 & 46.84 & 4.42 & 8.84 & 2.73 & 11.99 \\
\hline
\end{tabular}


Table 4. Cont'd

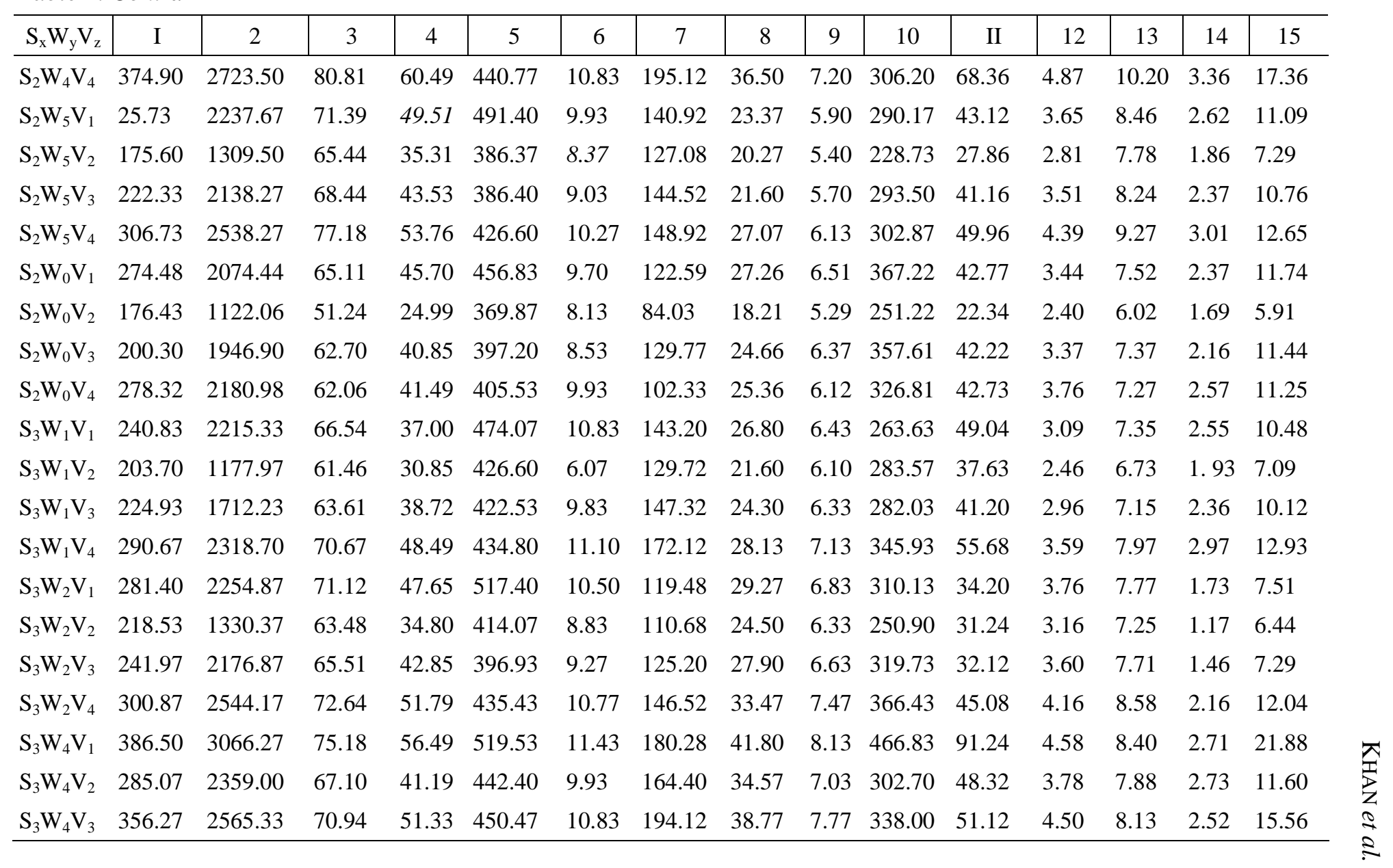


Table 4. Cont'd

\begin{tabular}{|c|c|c|c|c|c|c|c|c|c|c|c|c|c|c|c|}
\hline $\mathrm{S}_{\mathrm{x}} \mathrm{W}_{\mathrm{y}} \mathrm{V}_{\mathrm{z}}$ & I & 2 & 3 & 4 & 5 & 6 & 7 & 8 & 9 & 10 & II & 12 & 13 & 14 & 15 \\
\hline $\mathrm{S}_{3} \mathrm{~W}_{3} \mathrm{~V}_{4}$ & 415.07 & 3668.70 & 76.85 & 63.66 & 475.53 & 12.27 & 210.40 & 45.17 & 9.57 & 486.63 & 109.3 & 5.04 & 9.38 & 4.07 & 27.05 \\
\hline $\mathrm{S}_{3} \mathrm{~W}_{5} \mathrm{~V}_{1}$ & 321.87 & 2411.33 & 74.16 & 51.76 & 520.73 & 9.55 & 176.80 & 38.03 & 7.33 & 384.13 & 74.27 & 4.05 & 8.10 & 3.14 & 20.03 \\
\hline $\mathrm{S}_{3} \mathrm{~W}_{5} \mathrm{~V}_{2}$ & 350.03 & 1474.03 & 65.17 & 38.22 & 471.00 & 9.95 & 153.20 & 30.57 & 6.63 & 331.83 & 50.52 & 3.21 & 758 & 2.37 & 13.85 \\
\hline $\mathrm{S}_{3} \mathrm{~W}_{5} \mathrm{~V}_{3}$ & 280.27 & 2307.90 & 65.75 & 45.77 & 414.60 & 8.84 & 174.00 & 35.07 & 7.17 & 317.27 & 51.76 & 4.02 & 7.89 & 2.94 & 14.28 \\
\hline $\mathrm{S}_{3} \mathrm{~W}_{5} \mathrm{~V}_{4}$ & 352.37 & 2601.93 & 74.93 & 55.36 & 162.03 & 11.77 & 186.80 & 40.30 & 7.67 & 358.77 & 76.56 & 4.43 & 9.10 & 3.65 & 20.71 \\
\hline $\mathrm{S}_{3} \mathrm{~W}_{5} \mathrm{~V}_{1}$ & 245.47 & 2137.80 & 66.17 & 44.54 & 495.02 & 11.07 & 132.92 & 27.73 & 6.67 & 326.03 & 47.68 & 3.22 & 7.56 & 2.72 & 13.12 \\
\hline $\mathrm{S}_{3} \mathrm{~W}_{5} \mathrm{~V}_{2}$ & 184.63 & 1251.03 & 60.87 & 31.23 & 412.44 & 9.43 & 116.92 & 22.43 & 6.36 & 267.10 & 30.82 & 2.56 & 6.94 & 2.13 & 8.43 \\
\hline $\mathrm{S}_{3} \mathrm{~W}_{5} \mathrm{~V}_{3}$ & 200.96 & 2042.80 & 63.11 & 40.47 & 403.77 & 10.37 & 134.52 & 24.13 & 6.60 & 355.97 & 45.48 & 3.19 & 7.35 & 2.61 & 12.53 \\
\hline $\mathrm{S}_{3} \mathrm{~W}_{5} \mathrm{~V}_{4}$ & 268.58 & 2426.33 & 70.78 & 47.70 & 434.36 & 11.73 & 150.68 & 30.47 & 7.24 & 358.73 & 55.20 & 3.99 & 8.28 & 3.24 & 15.11 \\
\hline $\mathrm{S}_{3} \mathrm{~W}_{0} \mathrm{~V}_{1}$ & 251.68 & 1919.56 & 55.99 & 37.48 & 529.09 & 10.13 & 93.89 & 26.38 & 5.65 & 305.68 & 37.14 & 2.85 & 6.74 & 1.96 & 9.70 \\
\hline $\mathrm{S}_{3} \mathrm{~W}_{0} \mathrm{~V}_{2}$ & 16.341 & 1236.14 & 60.07 & 32.99 & 409.70 & 9.00 & 110.75 & 25.56 & 6.15 & 268.44 & 29.29 & 2.71 & 7.07 & 1.41 & 7.96 \\
\hline $\mathrm{S}_{3} \mathrm{~W}_{0} \mathrm{~V}_{3}$ & 207.78 & 1845.76 & 55.97 & 32.72 & 423.70 & 9.53 & 94.21 & 22.71 & 5.59 & 344.09 & 34.02 & 2.75 & 6.50 & 1.62 & 9.31 \\
\hline $\mathrm{S}_{3} \mathrm{~W}_{0} \mathrm{~V}_{4}$ & 262.33 & 2363.89 & 71.70 & 49.11 & 428.40 & 10.90 & 150.62 & 31.27 & 6.89 & 343.63 & 49.81 & 3.83 & 8.33 & 2.83 & 13.22 \\
\hline $\mathrm{LSD}_{0.05}$ & 45.83 & 260.30 & 11.14 & 8.39 & 76.06 & 1.11 & 13.28 & 5.52 & 0.96 & 52.45 & 6.20 & 0.77 & 1.45 & 0.39 & 0.96 \\
\hline CV (\%) & 10.61 & 7.65 & 10.28 & 11.91 & 11.11 & 7.21 & 6.11 & 11.72 & 8.92 & 9.06 & 8.01 & 13.20 & 11.4 & 10.5 & 10.16 \\
\hline
\end{tabular}

$\mathrm{S}=$ Growth stage, $\mathrm{W}=$ Water, $\mathrm{V}=$ Cultivar, $\mathrm{x}+1,2,3 ; \mathrm{y}=0,1,2,3,4$, and $\mathrm{z}=1,2,3,4$.

$1=$ No. of leaves per plant $2=$ Leaf area per plant $\left(\mathrm{cm}^{2}\right), 3=$ plant height $(\mathrm{cm}), 4=$ Canopy diameter $(\mathrm{cm}), 5=$ Root lenght $(\mathrm{cm}), 6=$ Root volume (cc), $7=$ No. of fruits per plant, 8= Fruit length $(\mathrm{mm}), 9=$ Fruit diameter $(\mathrm{mm}), 10=$ Individual fruit weight (mg), 11= Fruit yield per plant (g), 12= Leaf dry weight (g), 13= Stem dry weight (g), 14= Root dry weight (g), 15= Fruit dry weight per plant (g). 
reduction in number of fruits was, however, compensated by the increase in the fruit weight to some extent. The decrease in fruit weight in the matured stage in stress treatments might be due to the competition between vegetative and reproductive organs which reflected on the yield. Because, in indeterminate crops, vegetative growth and reproductive processes occur concurrently and overlap. So, there arises a competitive situation between vegetative and reproductive organs (Beeg and Turner, 1976).

The accession $V_{4}$ gave the highest value for all the parameters in combination with all the water treatments (Table 4). But only deviation was root length which was in second position for all the water treatments. It may be due to the tendency of roots in searching of moisture due to mild stress situation with $\mathrm{W}_{4}$ water treatment. Here, the highest root length producing accession was $\mathrm{V}_{1}$, which was also selected as a water stress tolerant accession. But small difference in root length could not influence any one of the parameters. The best performance of the accession $\mathrm{V}_{4}$ with all the water treatments including stress treatments proved its tolerance to water stress. On the other hand, the accession $\mathrm{V}_{2}$ produced the lowest values of the selected parameters in regards to watering sequences and growth stages. The water treatment $\mathrm{W}_{3}$ at all the growth stages in combination with the accession $V_{1}$ produced the highest values of all the parameters excepting root length (Table 4). The two stress treatments. $\mathrm{W}_{5}$ and $\mathrm{W}_{0}$ in combination with the accessions produced lower values of all the parameters at all growth stages indicating water stress in them.

The excess water caused lower yield in chilli as reported by Wankhede and Morey (1984). The combined effect of $\mathrm{S}_{\mathrm{x}} \mathrm{W}_{\mathrm{y}} \mathrm{V}_{\mathrm{z}}$ produced significant difference in results for all the characters (Table 4$)$. The selected susceptible accessions $\left(\mathrm{V}_{2}\right.$ and $\left.V_{3}\right)$ produced lower values than those of the selected tolerant accessions $\left(V_{1}\right.$ and $\mathrm{V}_{4}$ ) in all combinations. The water treatment, $\mathrm{W}_{3}$ always gave the highest values of the parameters indicating that the optimum irrigation level was at 4 days interval for chilli accessions. The treatment, $\mathrm{W}_{4}$, in most cases, followed $\mathrm{W}_{3}$. The stress treatments of $\mathrm{W}_{1}, \mathrm{~W}_{2}, \mathrm{~W}_{5}$, and $\mathrm{W}_{0}$ always gave the lower values in combination with other factors.

In the case of individual fruit weight, accession $\mathrm{V}_{4}$ produced lower values than the susceptible accession $V_{3}$ in combination treatment of $S_{1} \times W_{0} \times V_{4}$, $\mathrm{S}_{2} \times \mathrm{W}_{0} \times \mathrm{V}_{4}$, and $\mathrm{S}_{3} \times \mathrm{W}_{0} \times \mathrm{V}_{4}$ (Table 4), but there was no influence of it in the fruit yield per plant. So, the difference was negligible. 


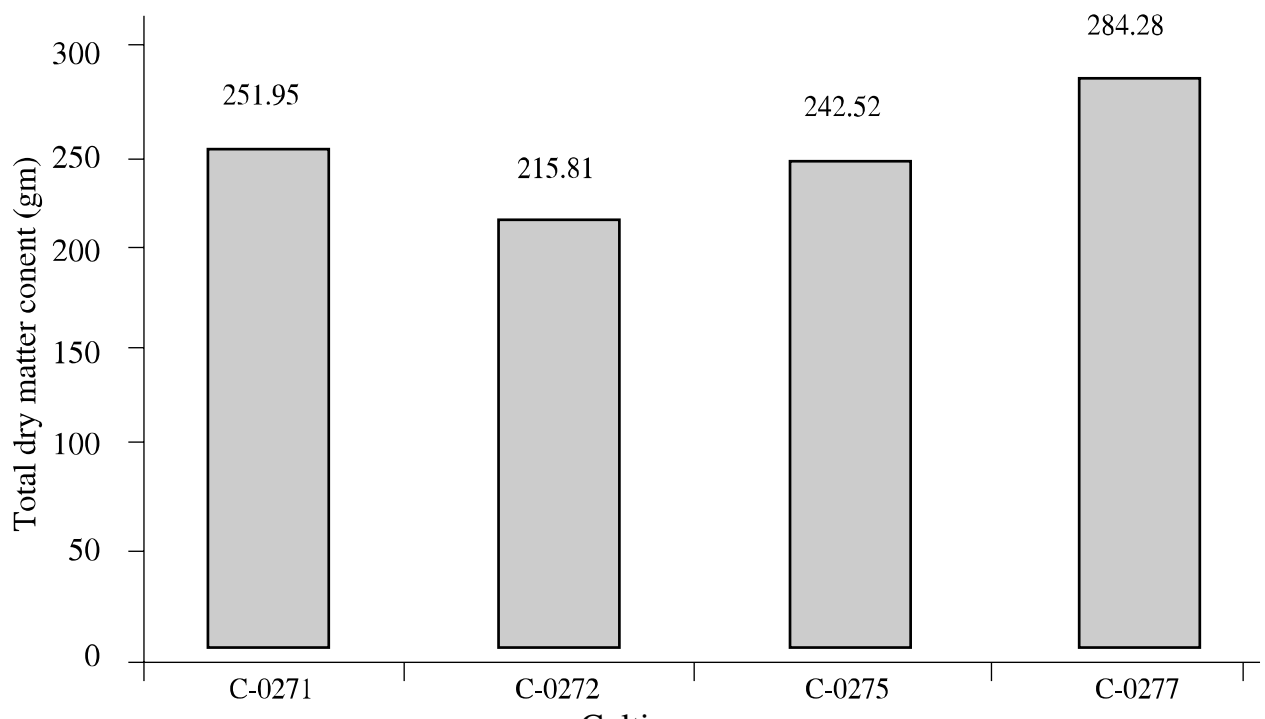

Fig. 1. Total dry matter content of four selected chilli cultivars treated under SxWxV treatment combinations

The total dry matter content was higher in the accessions $V_{1}$ and $V_{4}$ and lower in the accessions $V_{2}$ and $V_{3}$. The graph (Fig. 1) gave the justification for their identification as the water stress tolerant and susceptible accessions, respectively. The graph showed total dry matter content after water treatment application. On the basis of highest and lowest total dry matter content, the accessions $V_{4}$ and $V_{2}$ are selected from this study as water stress tolerant and susceptible accessions of chill, respectively.

\section{References}

Anonymous. 2005. Fertilizer Recommendation Guide-2005. Bangladesh Agricultural Research Council, New Air Port, Farmgate, Dhaka-l 215.

Ayob, K. 1986. Effect of availble soil moisture on the yield of chilli (Capsicum annuum). Technology Sayur Sayuran 2: 57-59.

Beese, F., R. Horton and P.J. Wierenga. 1982. Growth and yield response of chilli pepper to trickle irrigation. Agron. J. 74: 556-561.

Beese, F. and N. Moshrefi. 1985. Physiological reaction of chilli pepper to water and salt stress. Dripper Trickle Irrigation in Acton. 2: 646-651.

Beeg. J.E. and T .C. Turner. 1976. Crop water deficits. Adv. Agron. 28: 161-217.

Hamid, M.A. 1993. Drought tolerance study in Vicia faba. A Ph. D. Thesis submitted to Wye College, London. 
Hedge. D.M. 1989. Effect of soil moisture and nitrogen on plant water relations, mineral composition and productivity of bell pepper (Capsicum annuum). Indian J. Agron. 34(1):30-34,

Horton, R., F. Beese and P.J. Wierenga. 1982. Physiological response of chilli pepper to Prickle irrigation. Agron. .J. 74: 551-555.

Hossain M D. 1990. Cytogenetical studies in chilli (Capsicum annuum L.). An M. Phil Thesis. Submitted to Ralshahi University, Rajshahi. Bangladesh.

Muthukrishnan, C.R., T. Jhangaraj and R. Chaterjee. 1983. Chilli and Capsicum . In: Vegetable crops in India. Naya Prokash. calcutta. pp: 343-384.

Sadykov. I. M. and Zh. Yu. Mikhoct. 1981. Vegetable crops in India. Naya Prokash. Calcutta.

Smittle, D.A., W.L. Dickens and JR. Stansell. 1994. Irrigation regimes affect field and water use by bell papper. J. Amer. Soc. Hort. Sci. 119(5): 936-939.

Techawongstein. S., E. Nawata and S. Shigenaga. 1992. Effect of water stress at various stages of plant development on growth and yield of chilli pepper. Japan. J. Trop Agric. 36(1):51 -57.

Wankhede, B.N. and D.K. Morey. 1984. Effect of water levels of irrigation, nitrogen and potash on the growth and yield of chilli (Capsicum annuum L.). Panjabrao Krishi Vidyapeeth. Res. J. 8(2): 22-25. 